\title{
Characterization and Expression of $\beta$-1,3-Glucanase Genes in Jujube Fruit Induced by the Microbial Biocontrol Agent Cryptococcus laurentii
}

\author{
Shi P. Tian, Hong J. Yao, Xin Deng, Xiang B. Xu, Guo Z. Qin, and Zhu L. Chan
}

\begin{abstract}
All authors: Key Laboratory of Photosynthesis and Molecular Environment Physiology, Institute of Botany, Chinese Academy of Sciences, Beijing 100093, China; and second, fourth, and sixth authors: Graduate School of the Chinese Academy of Sciences, Beijing 100049, China.
\end{abstract}

Accepted for publication 3 October 2006.

\section{ABSTRACT}

Tian, S. P., Yao, H. J, Deng, X., Xu, X. B., Qin, G. Z., and Chan, Z. L. 2007. Characterization and expression of $\beta$-1,3-glucanase genes in jujube fruit induced by the microbial biocontrol agent Cryptococcus laurentii. Phytopathology 97:260-268.

Two $\beta$-1,3-glucanase genes were cloned from jujube (Ziziphus jujuba Mill) fruit and designated Glu-1 and Glu-2 (GenBank accession numbers DQ012940 and DQ093571), respectively. The expression of Glu-1 and Glu-2 in jujube fruit in response to wounding and microbial biocontrol agent was evaluated by semi-quantitative reverse-transcription polymerase chain reaction analysis. Wounding and treatment with Cryptococcus laurentii stimulated an increase in $\beta$-1,3-glucanase (EC 3.2.1.39) activity in jujube fruit. Analysis of gene expression proved that Glu-1 was highly induced both by wounding and $C$. laurentii, whereas $G l u-2$ was broadly not responsive to the yeast. The expression of Glu-1 was noticeably enhanced with increased concentrations of $C$. laurentii, suggesting that Glu-1 may play a role in defense responses to fungal pathogens. The results hold true at the levels of gene activation and enzyme accumulation in jujube fruit treated by both stimuli, resulting in a significant decrease in disease incidence and lesion diameter, thus providing evidence that changes in $\beta-1,3$-glucanase activity are related to expression of the genes. Taken together, these findings suggest the possible use of $\beta$-1,3-glucanase activity as a biochemical marker for screening jujube fruit against fungal pathogens, and also provide a mechanistic framework for the functions of $\beta$-1,3-glucanase in defense responses.
Plants have developed a range of defense mechanisms against pathogen attack, including the induction and accumulation of pathogenesis-related (PR) proteins, such as $\beta$-1,3-glucanases and chitinases (11). PR proteins are strongly induced in response to wounding or infection by pathogens and accumulate abundantly at the site of infection, contributing to systemic acquired resistance $(29,40)$. The defense response in plants is complex and involves both structural and biochemical barriers (42). $\beta-1,3-$ Glucanase hydrolyses $\beta$-1,3-linked glucans, a structural component of fungal cell walls, and therefore is considered to be involved in the plant defense mechanism against fungal infection (7). $\beta-1,3-G l u c a n a s e s$ have been reported from many different plant species in relation to development and in response to a variety of stimuli, including growth regulators and chemical elicitors $(24,34)$. Also, Chang et al. (5) reported that expression of $\beta$-1,3-glucanases was induced by fungal infection.

Previous studies have demonstrated that $\beta$-1,3-glucanases are associated with plant reproductive biology and PR defense $(2,29,38,56)$. For example, $\beta-1,3$-glucanase genes (TomPR- $Q$ 'a and TomPR- $Q$ 'b) have been cloned from viroid-infected tomato plants (9). Characterization and expression of $\beta$-1,3-glucanase genes in defense response to pathogens also has been carried out in peach fruit $(25,44)$. $\beta-1,4$-Glucanases are highly expressed in strawberry (31) and peach (46), supporting a role in fruit softening.

Recently, microbial biocontrol agents have been shown to elicit defense mechanisms of the host $(10,12)$. Production of cell-wall

Corresponding author: S. P. Tian; E-mail address: tsp@ibcas.ac.cn

DOI: 10.1094/PHYTO-97-3-0260

(C) 2007 The American Phytopathological Society lytic enzymes and induction of host resistance are considered to be an important action of microbial biocontrol agents against pathogenic fungi $(17,32)$. Biocontrol efficiency of antagonists may be related to their ability to induce PR proteins in the host (22). Previous experiments have indicated that Pichia membranefaciens and Candida guilliermondii are able to induce chitinase and $\beta$-1,3-glucanase activity in vitro, and to induce an increase in $\beta$-1,3-glucanase and chitinase activities in the wounds of nectarine fruit, resulting in beneficial control for the disease caused by Rhizopus stolonifer (14). However, it is not fully understood how biocontrol agents induce $\beta$-1,3-glucanase and block fungal attack. Moreover, little information exists as to whether $\beta-1,3-$ glucanase activity present in fruit tissues actually exhibits sufficient anti-fungal activity or accumulates to a high enough level to block fungal attack.

In previous studies, Penicillium expansum and Alternaria alternata were reported to be major pathogens causing postharvest decay of jujube fruit in storage $(39,45)$. The objectives of this work was, first, to investigate the inhibitory effects of Cryptococcus laurentii on $P$. expansum and A. alternata both in vitro and in jujube fruit; second, to measure population dynamics of the yeast with and without the fungal pathogens in the wounds of jujube fruit at different temperatures; and, last, to determine the effects of $C$. laurentii inoculation on $\beta$-1,3-glucanase activity in jujube fruit. Two $\beta$-1,3-glucanase genes were cloned from jujube fruit using reverse-transcription polymerase chain reaction (RTPCR) and rapid amplification of cDNA ends (RACE) techniques. Characterization and expression of the genes in jujube fruit after wounding and the yeast inoculation with different concentrations was evaluated by semi-quantitative RT-PCR analysis. The possible mechanisms of $\beta$-1,3-glucanase involved in fruit defense responses to fungal pathogens then are discussed. 


\section{MATERIALS AND METHODS}

Fruit and fungi. Jujube fruit (Ziziphus jujuba Mill. cv. Dongzao) were harvested at commercial maturity from an orchard in Binzhou, Shandong Province, China, and transported to Beijing the day after harvest. The fruit were sorted based on size without physical injuries or infections, disinfested with $2 \%$ (vol/vol) sodium hypochlorite for $2 \mathrm{~min}$, washed with tap water, and air dried prior to use.

Fungal pathogens $P$. expansum and $A$. alternata were isolated from decaying jujube fruit and cultured on potato dextrose agar at $25^{\circ} \mathrm{C}$. Spores ( 2 weeks old) of the fungi were obtained by flooding the cultures with sterile distilled water containing $0.05 \%$ (vol/vol) Tween 80 . The suspensions were filtered through three layers of sterilized cheesecloth and adjusted to a concentration of $1 \times 10^{5}$ spores $/ \mathrm{ml}$ with the aid of a hemacytometer.

$C$. laurentii was isolated from the surface of peach fruit following the method described by Wilson et al. (51) and identified by CABI Bioscience Identification Services (International Mycological Institute, UK). The yeast was cultured in potato-dextrose broth (PDB) and adjusted to different concentrations of $1 \times 10^{7}$ and $1 \times 10^{8} \mathrm{CFU} / \mathrm{ml}$ according to the previous experiment (13).

Biocontrol assay with different concentrations of yeast. The fruit were wounded at the equator using a sterile nail. Aliquots of $20 \mu \mathrm{l}$ of a suspension of $C$. laurentii at $1 \times 10^{7}$ or $1 \times 10^{8} \mathrm{CFU} / \mathrm{ml}$ or sterile distilled water (as the control) were pipetted into each wound site (uniformly $4 \mathrm{~mm}$ deep by $3 \mathrm{~mm}$ wide). After $4 \mathrm{~h}$, $20 \mu \mathrm{l}$ of a spore suspension of $P$. expansum or A. alternata, containing $1 \times 10^{5}$ spores $/ \mathrm{ml}$, was inoculated into the wound. All fruit were placed in plastic boxes ( 250 by 150 by $50 \mathrm{~mm}$ ), then put in plastic film bag to maintain high relative humidity $(\approx 95 \%)$, and stored at 25 and $0^{\circ} \mathrm{C}$. Disease incidence and lesion diameter caused by $P$. expansum and A. alternata were determined after 4 days at $25^{\circ} \mathrm{C}$ and 25 days at $0^{\circ} \mathrm{C}$. Disease incidence was scored according to the number of decayed fruit. Each treatment was replicated three times with 10 fruit per replication and the experiment was conducted twice.

Population dynamics of $\boldsymbol{C}$. laurentii. One wound was made on each fruit. Then, $15 \mu \mathrm{l}$ of a cell suspension of $C$. laurentii at $1 \times 10^{7} \mathrm{CFU} / \mathrm{ml}$ alone or in combination with $15 \mu \mathrm{l}$ of a spore suspension of $P$. expansum or A. alternata at $1 \times 10^{5}$ spores $/ \mathrm{ml}$ were put into each wound. Inoculated fruit were placed in plastic film bags or stored at 25 and $0^{\circ} \mathrm{C}$. Wound tissue was removed at different times according to the experiment following the method of Usall et al. (47) with some modifications. The resulting cylinders of excised tissue $(10 \mathrm{~mm}$ deep by $10 \mathrm{~mm}$ in diameter $)$ from four fruit were placed in a mortar with $10 \mathrm{ml}$ of $0.05 \mathrm{M}$ sodium phosphate buffer at $\mathrm{pH} 7.0$ and ground with a pestle. Serial 10-fold dilutions were made in phosphate buffer. Then, $0.1 \mathrm{ml}$ of each dilution was spread on nutrient yeast dextrose agar medium in petri plates and inoculated at $25^{\circ} \mathrm{C}$. The colonies were counted at $48 \mathrm{~h}$ and expressed as $\log _{10} \mathrm{CFU}$ per wound. Each treatment contained three replicates with 20 fruit per replicate, and the experiment was repeated twice.

Evaluation of spore germination of fungal pathogens. The suspensions of $P$. expansum and A. alternata were prepared as described above. Aliquots of $100 \mu \mathrm{l}$ of the pathogen suspensions at $\approx 1 \times 10^{5}$ spores $/ \mathrm{ml}$ and $100 \mu \mathrm{l}$ of cell suspension of $C$. laurentii at $1 \times 10^{7} \mathrm{CFU} / \mathrm{ml}$ were transferred to a glass tube (180 by $25 \mathrm{~mm}$ ) containing $5 \mathrm{ml}$ of PDB. All tubes were placed on a rotary shaker at $100 \mathrm{rpm}$ at $25^{\circ} \mathrm{C}$. After $12 \mathrm{~h}$ of incubation, $\approx 200$ spores of each pathogen were measured for germination rate and germ tube elongation. Spores were considered germinated when germ tube length was equal to or greater than spore length. Each treatment was replicated three times and the experiment was repeated twice.

Determination of $\beta$-1,3-glucanase activity. Jujube fruit were treated by two methods to determine $\beta$-1,3-glucanase activity. In the wounding and inoculation experiment, there were three treatments, including (i) wounding alone, (ii) wounding and inoculation with $20 \mu \mathrm{l}$ of suspension of $C$. laurentii at $1 \times$ $10^{8} \mathrm{CFU} / \mathrm{ml}$, and (iii) nonwounding and noninoculation (as the control). In the second experiment, jujube fruit were dipped in the suspensions of $C$. laurentii at different concentrations of $1 \times 10^{6}$, $1 \times 10^{7}$, and $1 \times 10^{8} \mathrm{CFU} / \mathrm{ml}$, or in sterile distilled water (as the control) for $5 \mathrm{~min}$. The second method of inoculation (by dipping in the suspension of $C$. laurentii) is like commercial treatment, because jujube fruit are easily injured in harvest and, in general, there are some small wounds on the surface of the fruit. All fruit were stored in the same conditions as described above. Each treatment was applied to three replicates of 20 fruit each. Treatments were arranged in a randomized complete block design, and the experiment was repeated twice.

All extract procedures were conducted at $4{ }^{\circ} \mathrm{C}$. $\beta-1,3-$ Glucanase was assayed by measuring the amount of reducing sugar released from the substrate by the dinitrosalicilate method (21) with some modifications. Flesh samples $(10 \mathrm{~g})$ from 10 fruit were ground with $0.3 \mathrm{~g}$ of polyvinyl polypyrrolidone in $30 \mathrm{ml}$ of sodium acetate buffer $(50 \mathrm{mmol}$ per liter, $\mathrm{pH} 5.0)$ at $4^{\circ} \mathrm{C}$. Then, $250 \mu \mathrm{l}$ of enzyme preparation was incubated with $250 \mu \mathrm{l}$ of $0.5 \%$ laminarin (wt/vol) for $1 \mathrm{~h}$ at $37^{\circ} \mathrm{C}$. Next, $200 \mu \mathrm{l}$ of sterile distilled water was added to $50 \mu \mathrm{l}$ of the reaction mixture. The blank was the crude enzyme preparation mixed with laminarin with zero time incubation. The reaction was stopped by adding $250 \mu \mathrm{l}$ of 3,5-dinitrosalicilate and boiling for $5 \mathrm{~min}$ in a water bath. The solution was diluted with $4 \mathrm{ml}$ of distilled water and the amount of reducing sugars was measured spectrophotometrically at $500 \mathrm{~nm}$ using a UV-160 spectrophotometer (Shimadzu, Japan). Specific activity of $\beta$-1,3-glucanase was expressed as the formation of glucose equivalents at $1 \mu \mathrm{mol} / \mathrm{h} / \mathrm{mg}$ of protein.

Gene cloning by RT-PCR and RACE. Total RNA was isolated from jujube fruit $24 \mathrm{~h}$ after wounding according to Kay et al. (23). Reverse transcription (RT) was carried out with oligo $(\mathrm{dT})_{18}$ primer and AMV reverse transcriptase (TaKaRa, Dalian, China). The conserved domain of $\beta$-1,3-glucanase gene was amplified by PCR performed with the synthesized cDNA, Taq DNA polymerase, and a pair of degenerate primers as follows: $5^{\prime}-$ (A/G)TTGC(G/T)GT(A/T/G)GGAAATGAAG-3' (forward primer) and 5'-CAAG(A/T)GC(C/G)G(A/C)GTAAACAGC-3' (reverse primer). PCR cycling parameters were as follows: $94^{\circ} \mathrm{C}$ for $2 \mathrm{~min} ; 6$ cycles of $94^{\circ} \mathrm{C}$ for $30 \mathrm{~s}, 60^{\circ} \mathrm{C}$ for $30 \mathrm{~s}$, and $72^{\circ} \mathrm{C}$ for $1 \mathrm{~min} ; 25$ cycles of $94^{\circ} \mathrm{C}$ for $30 \mathrm{~s}, 60$ to $50^{\circ} \mathrm{C}$ for $30 \mathrm{~s}$, and $72^{\circ} \mathrm{C}$ for $1 \mathrm{~min} ; 8$ cycles of $94^{\circ} \mathrm{C}$ for $30 \mathrm{~s}, 50^{\circ} \mathrm{C}$ for $30 \mathrm{~s}$, and $72^{\circ} \mathrm{C}$ for $1 \mathrm{~min}$; and, finally, $72^{\circ} \mathrm{C}$ for $10 \mathrm{~min}$. PCR product was cloned into pGEM-T easy vector (Tiangen, Beijing) according to the manufacturer's instruction, and sequenced.

Full-length coding sequences for $\beta$-1,3-glucanase genes were obtained by $3^{\prime}$ and 5' RACE. For 3' RACE, RT was carried out as described above using an adaptor oligo (dT) $3^{\prime}$ primer (5'GGCTCGAGTTTTTTTTTT-3'). PCR then was performed using a gene-specific 5' primer (5'-GCTTACCCCTTTTTCGCTTACA$3^{\prime}$ ) designed according to sequence of the cloned conserved domain and the adaptor primer. Two PCR products were cloned and sequenced as described and were named Glu-1 and Glu-2. For 5' RACE of $G l u-1$, RT was performed with a $3^{\prime}$ gene-specific primer (GSP1: 5'-TATGCCTTAACAACATTC-3') designed according to the sequence obtained from the $3^{\prime}$ RACE fragment of Glu-1, PCR was carried out with the second gene-specific primer (GSP2: 5'GAAGCCCATCCAGTCTCTGTAACAAC-3') and the anchor primer-1 (5'-GGCCACGCGTCGACTAGTACG $\left.\left.{ }_{(18)}\right)^{\prime} 3^{\prime}\right)$. In order to improve specificity, a further round of PCR was performed with a nested gene-specific primer (GSP3: 5'-TTAATATCAATATTCTCCGGATCACTC- $3^{\prime}$ ) and an anchor primer-2 (5'-GGCCACGCGTCGACTAGTAC- $3^{\prime}$ ). The resulting PCR product was cloned and sequenced. To obtain the full-length sequence of the $5^{\prime}$ region of $G l u-1$, a second round of 5' RACE was performed as described 
above with another set of $5^{\prime}$ gene-specific primers (GSP4: 5'GGGAGTCCAACCACCAAT-3', GSP5: 5'-ATTCAAGACCAGTTCCACTAAAGG-3', and GSP6: 5'-CTTCATCAGGTGAGGGTATGTTATC-3').

The $5^{\prime}$ coding sequence for $G l u-2$ was obtained by $5^{\prime}$ RACE as described above with three $G l u-2$ gene-specific primers designed according to the sequences of obtained $3^{\prime}$ fragment of $G l u-2$ and the conserved domain: 5'-TGGAACAGAGCGTAGGC-3', 5'AATGGGAGGAGTTGTCG-3', and 5'-ATTTTGATGGAGTCGTTGAGGTTG-3'.

Semi-quantitative RT-PCR. Total RNAs were obtained at 0 , 12,24 , and $48 \mathrm{~h}$ from jujube fruit treated with $C$. laurentii at concentrations of $10^{8} \mathrm{CFU} / \mathrm{ml}$ or from jujube fruit treated with C. laurentii at $10^{6}$ to $10^{8} \mathrm{CFU} / \mathrm{ml}$ for $48 \mathrm{~h}$. RT reactions were carried out using $2 \mu \mathrm{g}$ of DNase-treated total RNA, $1 \mu \mathrm{g}$ of oligo$(\mathrm{dT})_{18}$ primer, $200 \mu \mathrm{M}$ dNTPs, $5 \times$ RT buffer, $10 \mathrm{mM}$ dithiothreitol, and $200 \mathrm{U}$ of AMV reverse transcriptase (TaKaRa) at $42^{\circ} \mathrm{C}$ for $50 \mathrm{~min}$ after preheating at $70^{\circ} \mathrm{C}$ for $10 \mathrm{~min}$ to denature secondary structures, and terminated by heating at $70^{\circ} \mathrm{C}$ for $15 \mathrm{~min}$. A two-step semi-quantitative RT-PCR method was used to measure gene expression of isolated $\beta$-1,3-glucanase genes according to Meadus (33) using an actin 2 (At3g18780) endogenous control to adjust the volume of each cDNA pool to give the same exponential phase PCR signal strength. Genespecific primers used included $G l u-1$ sense (5'-TCTACCATGGCAATGAATAATTTCCGAG-3') and antisense (5'-TGCCTGCAGTTACCAGTCTTTCATCTTAT- $\left.3^{\prime}\right)$ and Glu-2 sense ( $5^{\prime}-$

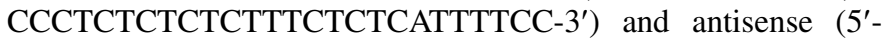
CAATAACCTGTAGGAAACTCGCAC-3') for $G l u-1$ and $G l u-2$, respectively. Cycling parameters were $94^{\circ} \mathrm{C}$ for $2 \mathrm{~min} ; 25$ cycles of $94^{\circ} \mathrm{C}$ for $30 \mathrm{~s}, 60^{\circ} \mathrm{C}$ for $30 \mathrm{~s}$, and $72^{\circ} \mathrm{C}$ for $90 \mathrm{~s}$; and, finally, $72^{\circ} \mathrm{C}$ for $10 \mathrm{~min}$. Both technical and biological repetitions were performed for all semi-quantitative RT-PCR experiments with RNAs from two independently treated fruit samples and two semi-quantitative RT-PCRs for at least one RNA for each treatment. The quantification was based on the level of product from an ethidium-bromide-stained gel using AlphaEaseFCTM software (version 4.0.0; Alpha Inotech Corporation, San Leandro, CA). Only band intensities that were $>1.5$-fold higher than the control $(0 \mathrm{~h}$ in each individual experiment $)$ were considered as inducible expression.

Sequence analysis. DNA and protein sequences were compared with the sequences deposited in GenBank using the BLAST program. N-terminal signal peptides were predicted using PSORT online version 6.4 software for plants (36). Cleavage of the signal peptide was predicted according to von Heijne (50). The consensus sequence for $N$-glycosylation $(\mathrm{NX}-\mathrm{S} / \mathrm{T})$, the conserved signature for glycosyl hydrolases family 17, and the amino acid residues of the catalytic nucleophile and catalytic acid were identified according to Henrissat (18) and Hoj et al. (19).

\section{RESULTS}

Interaction between yeast and pathogens in vitro and in vivo. $C$. laurentii significantly inhibited spore germination and germ tube growth of $P$. expansum and A. alternata in PDB (Table $1)$. For untreated controls, the germination rate of $P$. expansum and A. alternata reached 90.5 and $82.3 \%$ with a germ tube length of 105.8 and $91.2 \mu \mathrm{m}$, respectively. However, for treatments containing C. laurentii, only 40.2 and $25.2 \%$ of spores germinated, with germ tube length of 32.5 and $28.3 \mu \mathrm{m}$ for $P$. expansum and A. alternata, respectively.

Growth of $C$. laurentii in the wounds of jujube fruit in all treatments was observed with prolonged storage time at 25 and $0^{\circ} \mathrm{C}$ (Fig. 1). At the beginning of the experiment (time 0 ), the population of the yeast was $\approx 7.2 \times 10^{5} \mathrm{CFU} /$ wound, and increased to $1.3 \times 10^{7} \mathrm{CFU}$ at $25^{\circ} \mathrm{C}$ and $5.1 \times 10^{6} \mathrm{CFU}$ at $0^{\circ} \mathrm{C}$. This corresponded to an 18.1- and 7.1-fold growth increase compared with the initial inoculum at 25 and $0^{\circ} \mathrm{C}$, respectively. In addition, the amount of yeast in the wounds when the pathogens were present was significantly higher than in the absence of pathogens. These phenomena indicated that the presence of pathogens in the wound could stimulate an increase in yeast numbers. It also was clear that $C$. laurentii has adapted to low-temperature environments, because it thrived even at $0^{\circ} \mathrm{C}$.

Effect of different concentrations of yeast on decay control. The effectiveness of $C$. laurentii against $P$. expansum and $A$. alternata in jujube fruit was positively correlated with concentrations of the yeast. At $1 \times 10^{7} \mathrm{CFU} / \mathrm{ml}, C$. laurentii significantly $(P<$ $0.05)$ reduced disease incidence and lesion diameter caused by both fungal pathogens compared with the control. Furthermore, better disease control was observed at inoculum concentrations of $1 \times 10^{8}$ than at $1 \times 10^{7} \mathrm{CFU} / \mathrm{ml}$ at both 25 and $0^{\circ} \mathrm{C}$ (Figs. 2 and 3). After storage at $25^{\circ} \mathrm{C}$ for 4 days, disease incidence in the control fruit reached $100 \%$ (with 11-mm lesion diameter), whereas a 78.7 and $20.7 \%$ change in disease incidence (with 8- and 5-mm lesion diameter) caused by $P$. expansum was found in the fruit treated with $C$. laurentii at $1 \times 10^{7}$ and $1 \times 10^{8} \mathrm{CFU} / \mathrm{ml}$, respectively. A 60.3 and $3.3 \%$ change in disease incidence (with 5- and 3-mm lesion diameter) by A. alternata was observed in the same conditions (Fig. 2). Low temperature delayed disease development. The control fruit showed $100 \%$ disease incidence after storage at $0^{\circ} \mathrm{C}$ for 25 days, whereas the fruit treated by C. laurentii at $1 \times 10^{8} \mathrm{CFU} / \mathrm{ml}$ had only 13.3 and $23.3 \%$ disease incidence resulting from $P$. expansum and A. alternata, respectively (Fig. 3). In addition, lesion diameters caused by both diseases were reduced significantly $(P<0.05)$ by increasing concentration of $C$. laurentii at both 25 and $0^{\circ} \mathrm{C}$ (Figs. 2 and 3).

Changes in $\beta$-1,3-glucanase by wounding and yeast inoculation. Activity of $\beta-1,3$-glucanase in the control fruit changed slightly during the experiment periods; however, wounding stimulated an increase in $\beta$-1,3-glucanase activity between 24 and $48 \mathrm{~h}$ after treatment. $\beta-1,3$-Glucanase activity in the fruit wounded and inoculated with $C$. laurentii increased more markedly and was present at significantly higher levels compared with wounding alone or the untreated controls (Fig. 4A). Activity of $\beta-1,3-$ glucanase in $C$. laurentii-treated fruit increased by more than 2.8 and 2.4-fold than the control and by 2.3- and 1.7-fold compared with the wounded, noninoculated fruit at 24 and $48 \mathrm{~h}$, respectively, after treatment. In addition, $\beta$-1,3-glucanase activity was significantly enhanced with increased concentrations of the yeast and showed the peak value at $48 \mathrm{~h}$ in all treatments (Fig. 4B). Fruit dipped in a suspension of $C$. laurentii at $1 \times 10^{8} \mathrm{CFU} / \mathrm{ml}$ gave rise to the highest activity of $\beta$-1,3-glucanase among all

TABLE 1. Effect of Cryptococcus laurentii at $1 \times 10^{7} \mathrm{CFU} / \mathrm{ml}$ on spore germination and germ tube length of Penicillium expansum and Alternaria alternata in potato dextrose broth after $12 \mathrm{~h}$ of incubation at $25^{\circ} \mathrm{C}^{\mathrm{z}}$

\begin{tabular}{lccccc}
\hline & \multicolumn{2}{c}{ Spore germination $(\%)$} & & \multicolumn{2}{c}{ Germ tube length $(\mu \mathrm{m})$} \\
\cline { 2 - 3 } \cline { 5 - 6 } Treatments & P. expansum & A. alternata & P. expansum & A. alternata \\
\hline Control & $90.5 \pm 1.11 \mathrm{a}$ & $82.3 \pm 0.52 \mathrm{a}$ & & $105.8 \pm 2.54 \mathrm{a}$ & $91.2 \pm 2.13 \mathrm{a}$ \\
C. laurentii & $40.2 \pm 0.15 \mathrm{~b}$ & $25.2 \pm 0.63 \mathrm{c}$ & & $32.5 \pm 0.29 \mathrm{~d}$ & $28.3 \pm 0.45 \mathrm{~d}$ \\
\hline
\end{tabular}

${ }^{\mathrm{z}}$ Means in a column followed by a different letter differ significantly at $P=0.05$ by Duncan's multiple range tests, and \pm data represent standard deviations of the means. 
treatments, but activity of $\beta$-1,3-glucanase in the control fruit was lowest throughout the duration of the experiment.

Cloning $\beta$-1,3-glucanase genes from jujube fruit. Full-length cDNA sequences of two distinct $\beta$-1,3-glucanase genes were obtained from jujube fruit $24 \mathrm{~h}$ after wounding and designated as Glu-1 and Glu-2 (GenBank accession nos. DQ012940 and DQ093571, respectively). The cDNA of Glu-1 was composed of 1,265-bp nucleic acids with an 87-bp 5' untranslated region, a
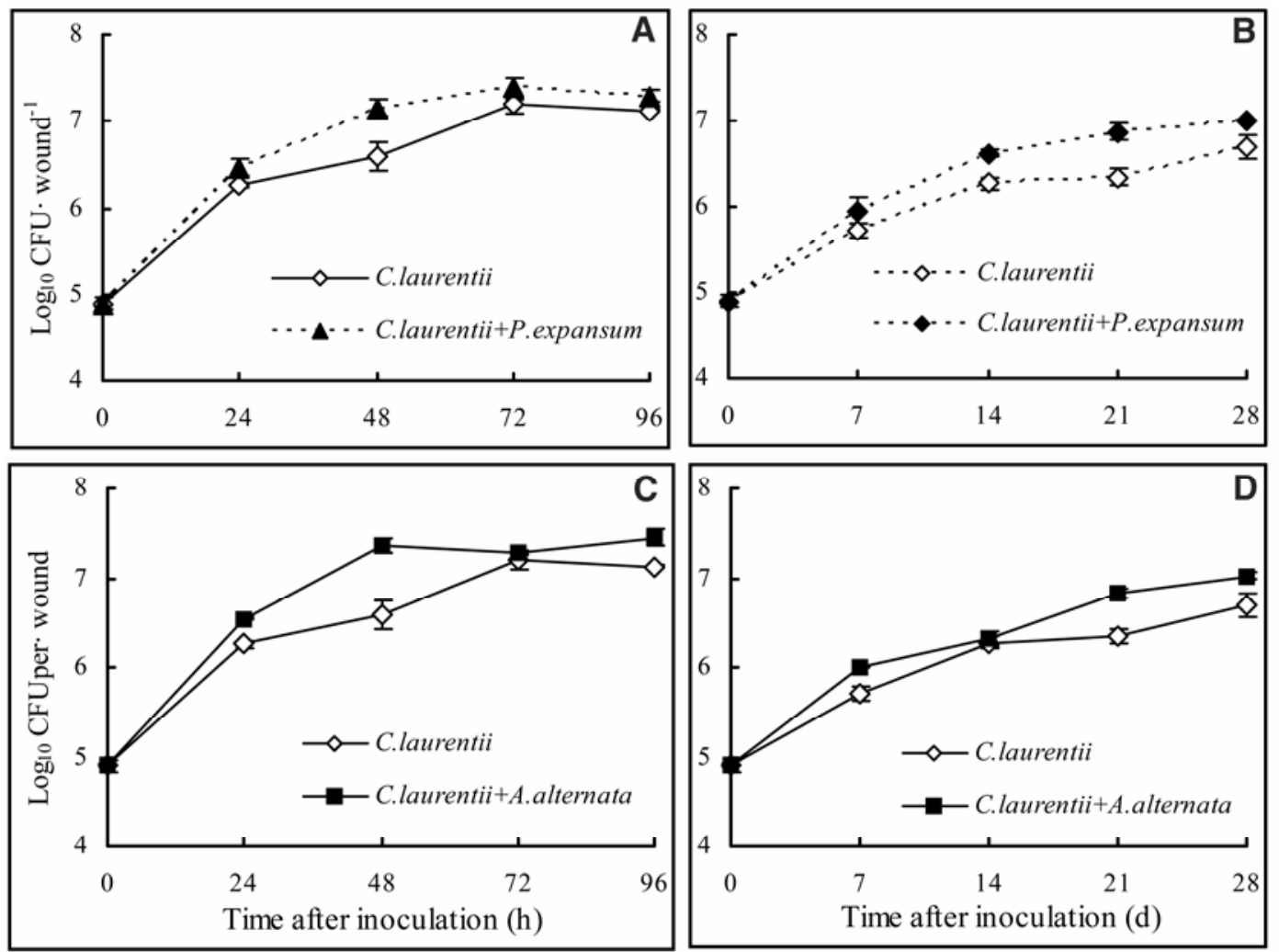

Fig. 1. Population dynamics of Cryptococcus laurentii with and without fungal pathogens in the wounds of jujube fruit at $\mathbf{A}$ and $\mathbf{C}, 25^{\circ} \mathrm{C}$ and $\mathbf{B}$ and $\mathbf{D}, 0^{\circ} \mathrm{C}$. Bars represent standard deviations of the means.
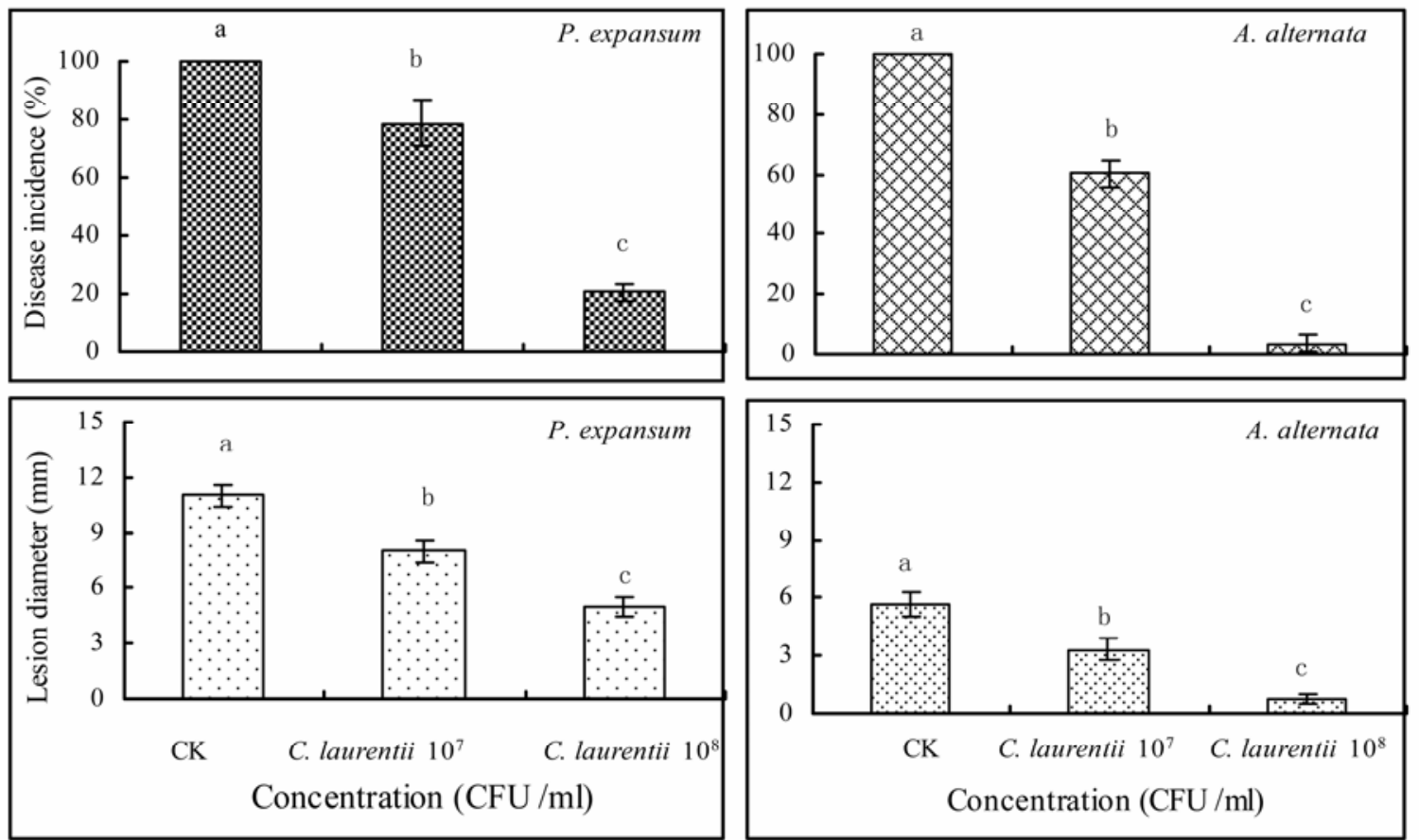

Fig. 2. Effects of different concentrations of Cryptococcus laurentii on disease incidence and lesion diameter caused by Penicillium expansum and Alternaria alternata in jujube fruit stored at $25^{\circ} \mathrm{C}$ after 4 days. The fruit were wounded and inoculated with C. laurentii at different concentrations of $1 \times 10^{7}$ and $1 \times$ $10^{8} \mathrm{CFU} / \mathrm{ml}$. Bars represent standard deviations of the means. Values followed by different letter were significantly different according to Duncan's multiple range test at $P<0.05$. 
1,134-bp open reading frame (ORF), and a 41-bp 3' untranslated region terminating in a poly (A) tail. An N-terminal signal peptide consisting of 22 amino acids was identified from the encoding protein using PSORT software, indicating that the Glu-1 protein was likely to be transferred to the extracellular space. Cleavage of this signal peptide was predicted to yield a mature protein of $\approx 39 \mathrm{kDa}$ with a calculated isoelectric point of 5.9. A consensus sequence for NX-S/T was located at amino acid positions 281 to 283 (N-E-S), indicating that Glu-1 may be a glycoprotein similar to other previously characterized $\beta-1,3$-glucanase proteins. The amino acid residues of the catalytic nucleophile and catalytic acid were glutamic acids at position 271 and 334 . Glu-1 shared significant identity with sequences of identified $\beta$-1,3-glucanases from plants such as Arabidopsis (accession no. AAM67102, 77\%), rice (AP005446, 64\%) potato (S31196, 49\%), and tobacco (AB050628, 41\%).

The cDNA of Glu-2 contained a 70-bp 5' untranslated region, a 1,407-bp ORF, and a 7-bp 3' untranslated region terminating in a poly (A) tail. The ORF encoded a 468-amino-acid polypeptide with a predicted $\mathrm{N}$-terminal signal peptide cleavage site at the 19th amino acid, indicating that Glu-2 also was likely to be an extracellular protein. The amino acid residues of the catalytic nucleophile and catalytic acid were glutamic acids at position 260 and 323, respectively. A protein database search showed that Glu2 had significant identity to putative $\beta$-1,3-glucanase-like proteins from Arabidopsis (AAM66024, 71\%), tobacco (AB032530, $70 \%$ ), rice (XM468018, 56\%), and maize (AY542797, 39\%). Despite the similar cellular location and putative function, Glu-1 and
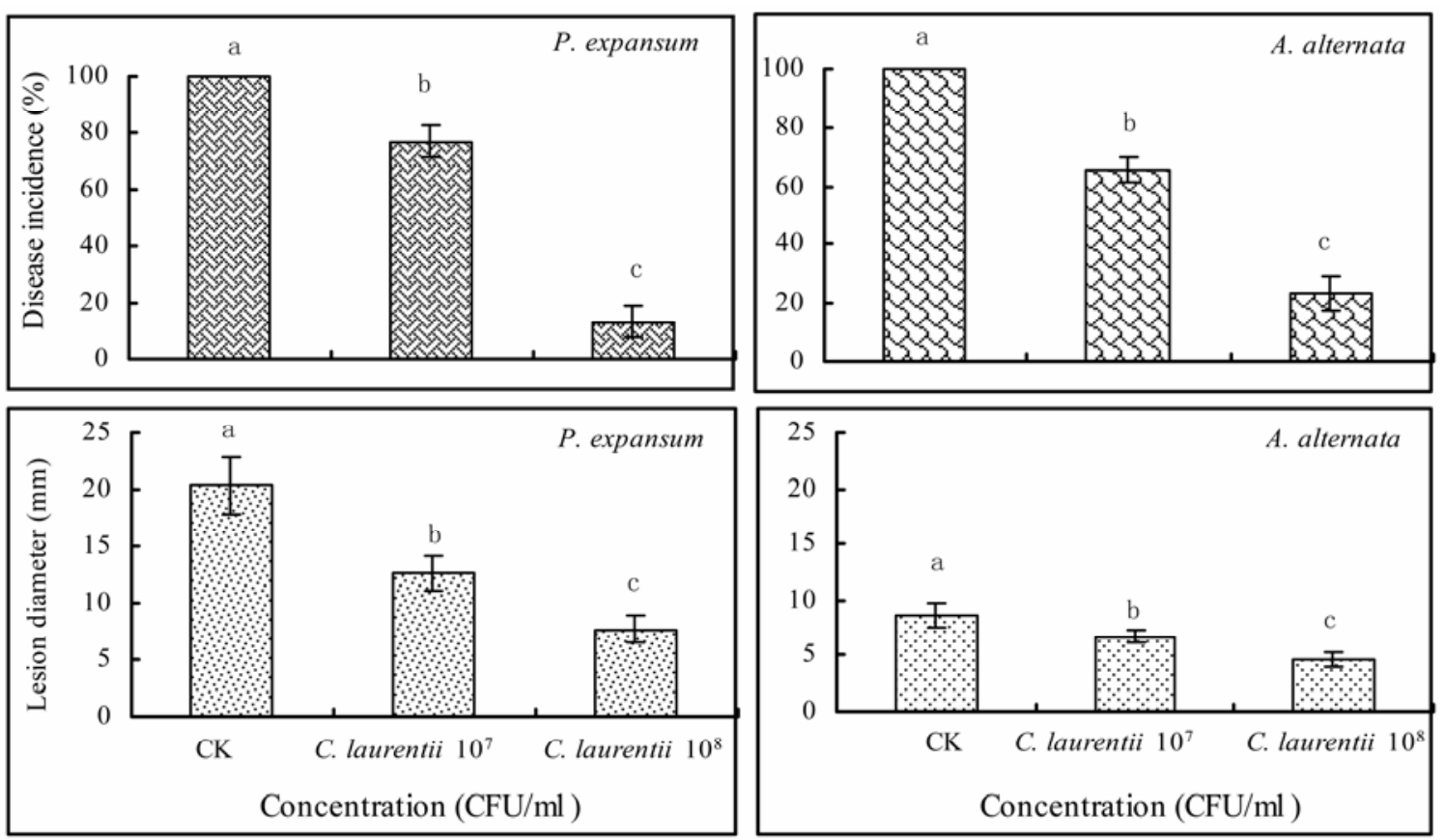

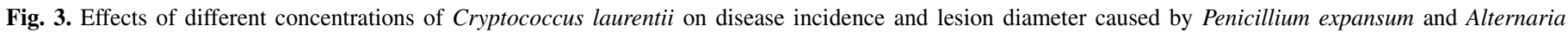

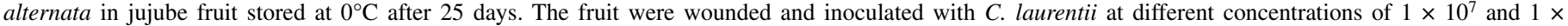

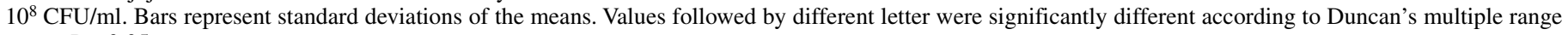
test at $P<0.05$.
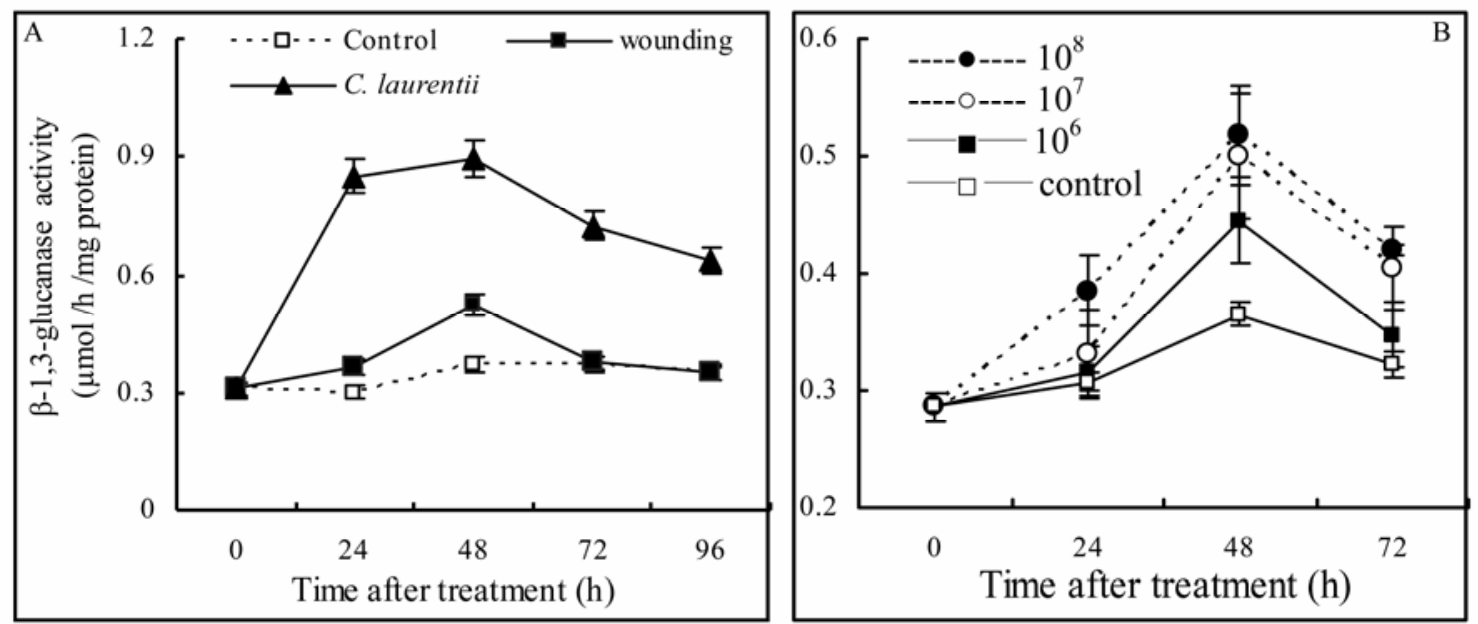

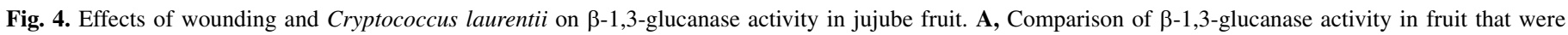

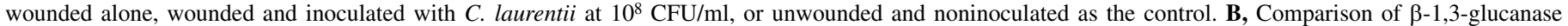

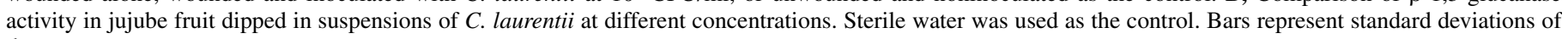
the means. 
Glu-2 shared only $43 \%$ identity at the amino acid level, suggesting that they may not be functionally redundant. Amino acid sequence comparisons showed that Glu-1 and Glu- 2 were only 33 and $39 \%$ identical to fruit-specific peach $\beta$-1,3-glucanase (AF435089) (25), 36 and 40\% identical to pathogen-induced soybean $\beta$-1,3-glucanase (U41323) (6), and 37 and $40 \%$ identical to fruit-specific banana $\beta$-1,3-glucanase (AF001523) (38), respectively. However, sequence alignment revealed that they all contained the conserved signature for glycosyl hydrolases family 17 , as indicated by the conserved glutamic acid residues of the catalytic nucleophile and catalytic acid (Fig. 5).

Expression of $\beta$-1,3-glucanase genes in jujube fruit is induced by wounding and yeast inoculation. Analysis of gene expression further supported the distinct roles of Glu-1 and Glu-2 in response to wounding and yeast (Fig. 6). Both genes were constitutively expressed in jujube fruit and responded to wounding by increased expression compared with untreated controls (1.88 \pm
$0.22-, 2.25 \pm 0.31-$, and $2.40 \pm 0.21$-fold increases were observed for Glu- 1 and $1.39 \pm 0.19-, 1.65 \pm 0.31-$, and $1.69 \pm 0.20$-fold increases were observed for Glu-2 at 12, 24, and $48 \mathrm{~h}$ after wounding, respectively). However, the genes differed in their expression pattern after yeast inoculation: $G l u-1$ expression level was induced with increasing period after inoculation and showed a peak value at $48 \mathrm{~h}(2.79 \pm 0.33-, 3.99 \pm 0.41-$, and $5.96 \pm 0.32-$ fold compared with the untreated control at 12,24 , and $48 \mathrm{~h}$, respectively), whereas $G l u-2$ expression after wounding and subsequent yeast inoculating was not different from that after wounding alone (1.54 $\pm 0.18-, 1.41 \pm 0.21$-, and $1.51 \pm 0.19$-fold compared with the untreated control at 12,24 , and $48 \mathrm{~h}$, respectively), suggesting that Glu-2 was unaffected by yeast inoculation. The actual relative band intensity values, which are well consistent with the images in Figure 6, revealed that Glu-1 was highly induced by both wounding and antagonist, whereas Glu-2 was broadly not responsive to yeast inoculation. Gene expression

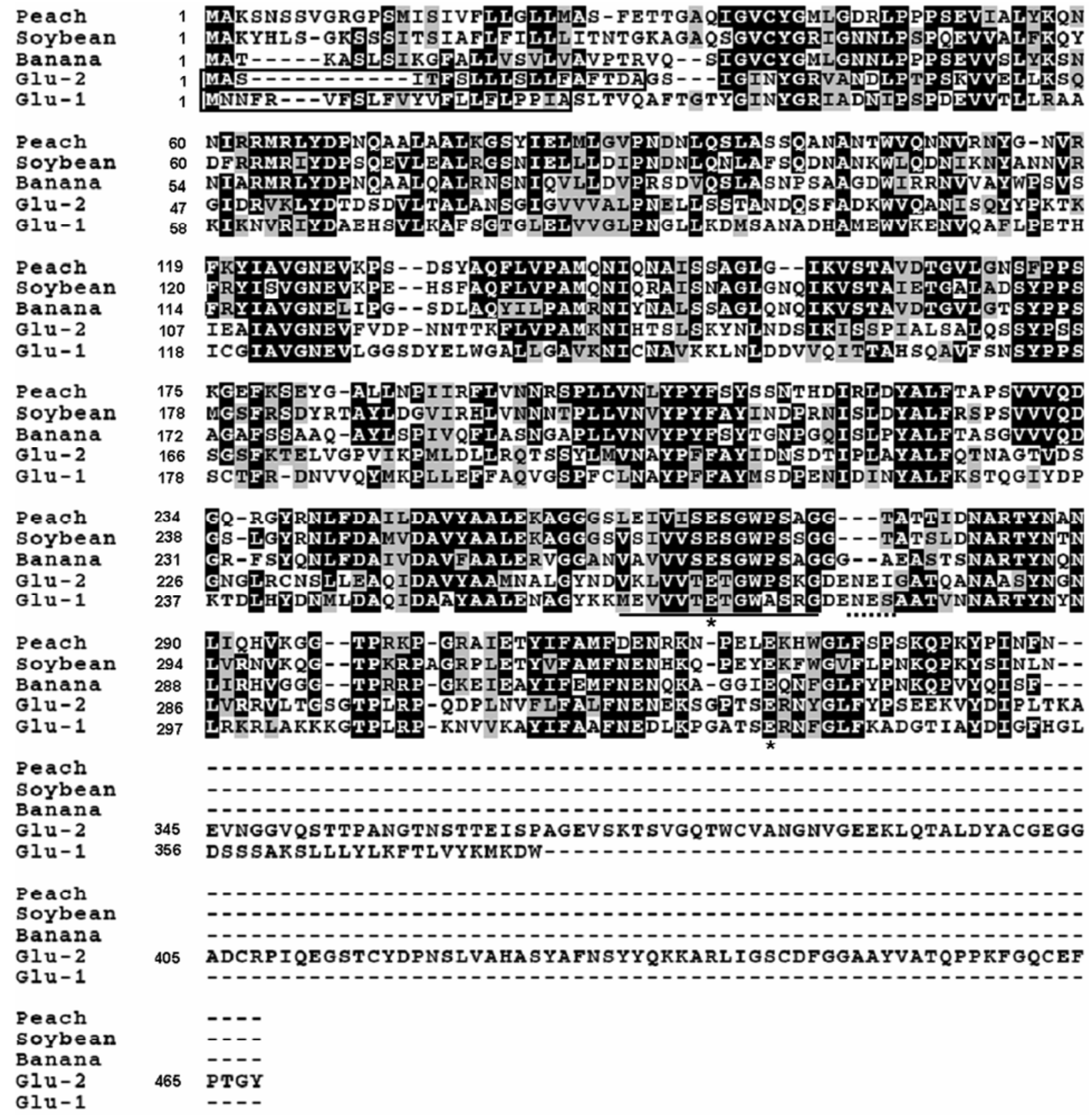

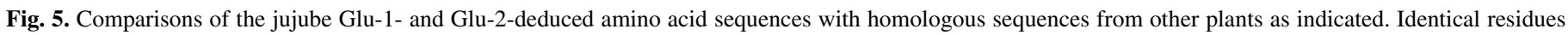

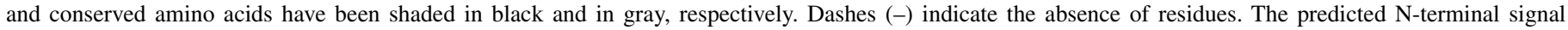

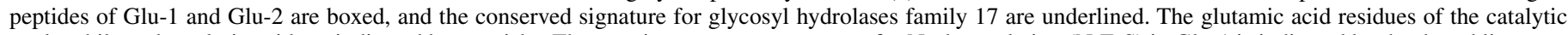
nucleophile and catalytic acid are indicated by asterisks. The putative consensus sequence for N-glycosylation (N-E-S) in Glu-1 is indicated by the dotted line. 
analysis of jujube fruit that was incubated in increasing concentrations (from $10^{6}$ to $10^{8} \mathrm{CFU} / \mathrm{ml}$ ) of yeast culture showed that Glu-1 was significantly stimulated $(1.76 \pm 0.22-, 2.18 \pm 0.18-$, and $2.97 \pm 0.31$-fold compared with the untreated control at yeast concentration of $10^{6}$ to $10^{8} \mathrm{CFU} / \mathrm{ml}$ for Glu-1 and $1.26 \pm 0.20-$, $1.04 \pm 0.13-$, and $1.28 \pm 0.31$-fold for Glu-2), whereas Glu-2 remained unchanged regardless of yeast concentration (Fig. 7). These results suggested that, in contrast to Glu-2, Glu- 1 is yeast responsive and may play a role in defense response of jujube fruit against fungal infection during the postharvest period.

\section{DISCUSSION}

In our previous studies, $C$. laurentii was isolated from the surface of apple fruit and evaluated to be effective in controlling postharvest diseases in jujube fruit $(39,45)$. In this study, we further found that $C$. laurentii could significantly limit spore germination and germ tube growth of $P$. expansum and $A$. alternata in PDB (Table 1), and showed a rapid increase in population dynamics in the wounds of jujube fruit, particularly when pathogens were present (Fig. 1). Meanwhile, C. laurentii could propagate rapidly in the wounds of jujube fruit $48 \mathrm{~h}$ after inoculation (Fig. 1), resulting in an effective decrease in disease incidence and lesion diameter caused by $P$. expansum and A. alternata (Figs. 2 and 3). In general, the mode of action of microbial biocontrol agents may involve nutrient competition, site exclusion, direct parasitism, and perhaps induced resistance (12). However, antagonist-pathogen interaction has been considered to play a major role in their biological activities (8). Some results indicated that the difference in biocontrol ability of yeasts against fungal pathogens might be relative to attachment to fungal hyphae (14, 52). Wisniewski et al. (52) found that yeast cells produce lytic enzymes that can enhance the attachment to hyphae of pathogens. Our previous results indicated that $P$. membranefaciens had a stronger capability of attaching to the fungal hyphae of $P$. expansum than Cryptococcus albidus did both on apple juice agar plates and in apple wounds by light microscopy and scanning electron microscopy observations, because the differences might be attributed to cell membrane surface proteins and protein signal recognition between yeast cells and pathogen hyphae (3).

Induction of disease resistance in a number of crops following treatment with microbial agents has been demonstrated and provides protection against a wide range of pathogens $(27,49)$. In harvested commodities, the induction of disease resistance by microbial antagonists has been suggested in recent years $(10,20)$. Protection of the fruit from the invasion of fungal pathogens appears due to involvement of a highly coordinated biochemical and structural defense system that helps ward off the spread of pathogens $(28,41)$. The onset of resistance often has been correlated with the accumulation of defense-related enzymes, such as chitinases, $\beta$-1,3-glucanases, phenylalanine ammonia lyases, and peroxidases $(12,55)$. Several in vitro experiments have indicated that $\beta$-1,3-glucanases and chitinases were able to partially degrade the cell walls and to inhibit mycelial growth or spore germination of some pathogenic fungi $(1,28)$. Furthermore, the antifungal effects were synergistically enhanced when both enzymes were present. In jujube fruit, $\beta$-1,3-glucanase activity was significantly induced by $C$. laurentii $24 \mathrm{~h}$ after inoculation (Fig. 4). This result is consistent with the temporal and spatial induction of defense-related enzymes and likely concomitantly with induced resistance (43). It also documents that jujube fruit were capable of responding to wounding and yeast, as seen in other crops $(10,15,22)$. Additionally, the induction of resistance was positively correlated with the concentration of biocontrol agents. Enhancing concentration of $C$. laurentii can induce an increase in $\beta$-1,3-glucanase activity (Fig. 4) and expression of the genes (Fig. 7), resulting in effective control of decay by $P$. expansum and A. alternata in jujube fruit (Figs. 2 and 3 ). We previously have demonstrated that yeast treatment induced synthesis of antioxidant enzymes and variety of total protein,

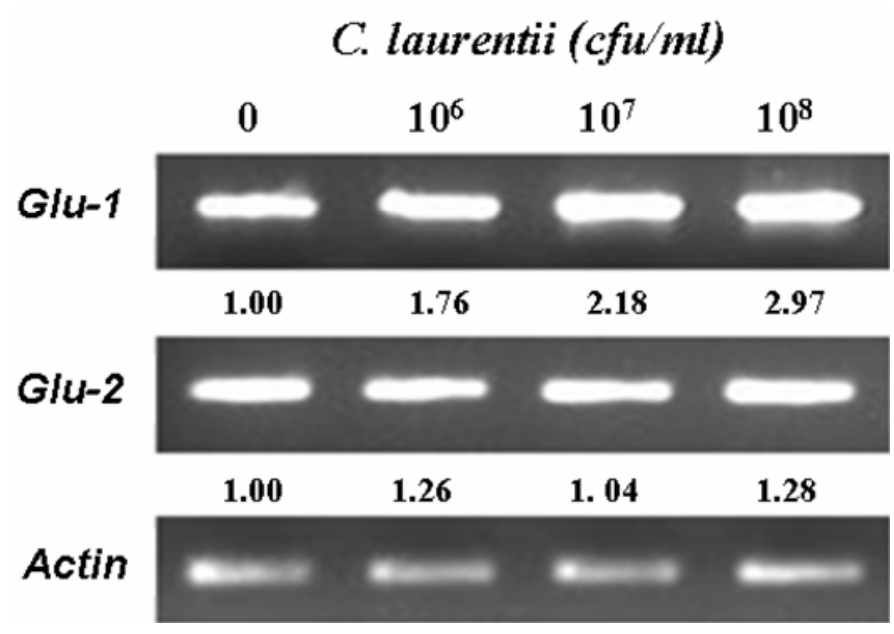

Fig. 7. Semi-quantitative reverse-transcription polymerase chain reaction analysis of Glu-1 and Glu-2 expression in response to different concentrations of Cryptococcus laurentii in jujube fruit. Total RNAs were obtained from jujube fruit treated with $C$. laurentii at $10^{6}$ to $10^{8} \mathrm{CFU} / \mathrm{ml}$ for $48 \mathrm{~h}$. The housekeeping gene actin 2 (At3g18780) was used as a control for normalizing mRNA quantity. Relative expression ratio of Glu-1 and Glu-2 in each yeastinoculated fruit compared with that in untreated fruit is shown below each band.

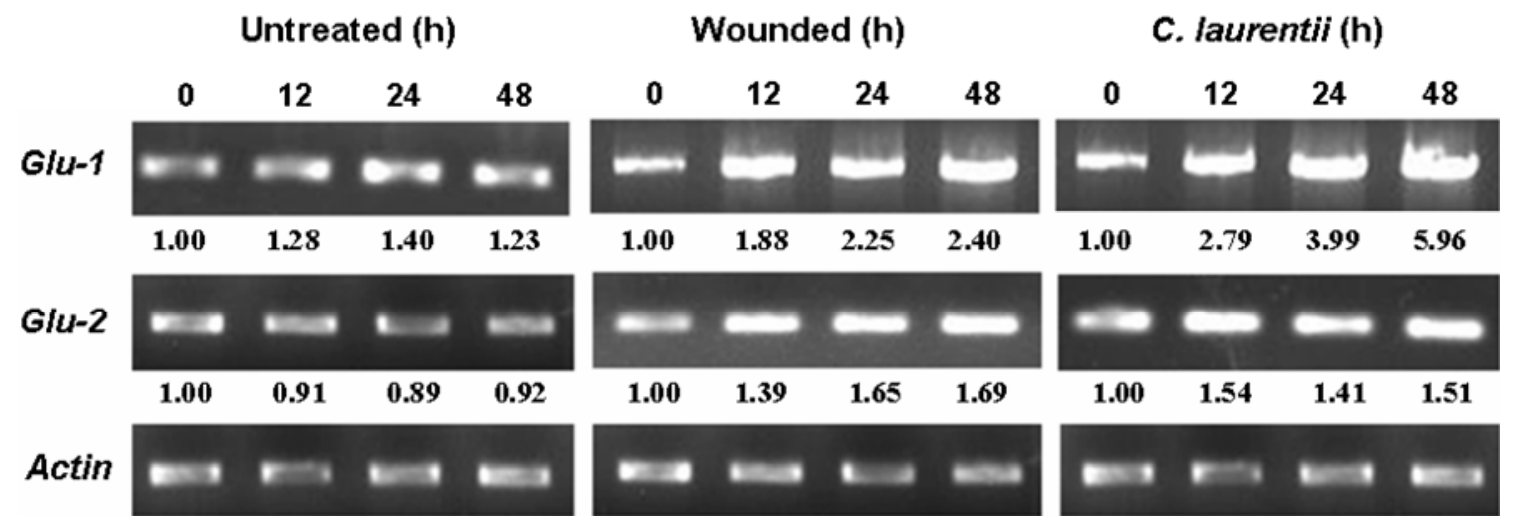

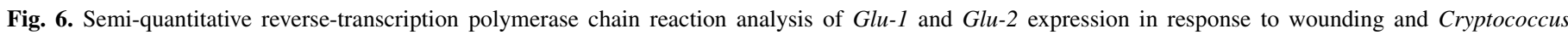

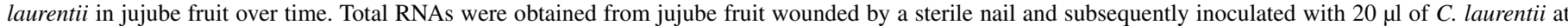

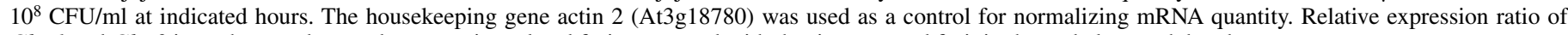
Glu-1 and Glu-2 in each wound-treated or yeast-inoculated fruit compared with that in untreated fruit is shown below each band. 
which may play a role in the resistance against blue mould rot in sweet cherry (4). This increased $\mathrm{H}_{2} \mathrm{O}_{2}$ has been proposed to be a signal leading to hypersensitive cell death, and activates many tolerance-related genes against pathogen attack (26).

Generally, $\beta-1,3$-glucanase genes in plant species exist in multiple isoforms (16). $\beta$-1,3-Glucanases from tobacco can be divided into three classes based on structural similarity: class I contains vacuolar (intracellular) $\beta$-1,3-glucanases with a basic isoelectric point (pI) and abundant mRNA transcripts in roots of healthy plants (42); class II contains acidic secreted $\beta-1,3-$ glucanases which are induced after infection by pathogen or elicitors (30) and appear to be localized in the extracellular compartment; and class III contains tobacco extracellular PR $\beta-1,3-$ glucanases which are induced by Tobacco mosaic virus infection and are more closely related to class II in structure, regulation, and function (37). Sequence analysis revealed that Glu-1 and Glu2 are acidic secreted $\beta$-1,3-glucanases, suggesting that they belonged to class II. Based on the observed spatial and temporal regulation of expression, $\beta-1,3$-endoglucanases appear to participate in different biological functions, such as plant reproductive biology and PR defense mechanisms against fungal attack (42). $\beta$-Glucanases also may be involved in other processes, such as in response to wounding and abiotic stress $(35,38,56)$. Expression of Glu-1 and Glu-2 was stimulated in jujube fruit 12 to $48 \mathrm{~h}$ after wounding (Fig. 6), suggesting that the timing and expression level of $\beta$-1,3-glucanase genes may be an important aspect in defense responses (53).

Glu-1 was highly induced by both wounding and inoculation with $C$. laurentii, particularly at 24 and $48 \mathrm{~h}$, whereas Glu-2 was not responsive (Fig. 6). These results are in agreement with $\mathrm{Wu}$ and Bradford (53), who detected expression of $\beta$-1,3-glucanase $(G l u B)$ in tomato leaves in response to wounding and methyl jasmonate treatment after $12 \mathrm{~h}$. Because $\beta$-1,3-glucanase was strongly induced by the biocontrol agent in jujube fruit, the localized expression of $\beta$-1,3-glucanase that would be in direct contact with the biotic environment might constitute an effective barrier to pathogen entry into the fruit. Additional support for this conclusion was derived from the study of $\mathrm{Wu}$ et al. (54) in tomato. There is compelling evidence that $\beta$-1,3-glucanase can act directly by degrading the pathogen cell wall or indirectly by releasing oligosaccharide elicitors of defense reaction, both of which are potential defense mechanisms against fungal infection $(6,21)$. These observations supported the notion that different members of $\beta$-1,3-glucanase probably are involved in various biological functions in plant defense response against a wide variety of pathogens $(30,37,48)$. Our findings open out a mechanistic framework for the functions of $\beta$-1,3-glucanase in fruit defense responses.

\section{ACKNOWLEDGMENTS}

This study was supported by the National Science Fund for Distinguished Young Scholars of China (30225030) and the National Natural Science Foundation of China (30430480). We thank J. Phillips for his suggestions on the manuscript.

\section{LITERATURE CITED}

1. Anfoka, C., and Buchenauer, H. 1997. Systemic acquired resistance in tomato against Phytophthora infestans by pre-inoculation with tobacco necrosis virus. Physiol. Mol. Plant Pathol. 50:85-90.

2. Castresana, C., de Carvalho, F., Gheysen, G. Habets, M. Inze, D., and van Montagu, M. 1990. Tissue-specific and pathogeninduced regulation of a Nicotiana plumbaginifolia $\beta$-1,3-glucanase gene. Plant Cell 2:1131-1143.

3. Chan, Z. L., and Tian, S. P. 2005. Interaction of antagonistic yeasts against postharvest pathogens of apple fruit and possible mode of action. Postharvest Biol. Technol. 36:215-223.

4. Chan, Z. L., and Tian, S. P. 2006. Induction of $\mathrm{H}_{2} \mathrm{O}_{2}$-metabolizing enzymes and total protein synthesis in sweet cherry fruit by Pichia membranefaciens and salicylic acid treatment. Postharvest Biol. Technol.
39:314-320.

5. Chang, M. M., Culley, D. E., and Hadwiger, L. A. 1993. Nucleotide sequence of a pea (Pisum sativam L.) $\beta$-1, 3-glucanase gene. Plant Physiol. 101:1121-122.

6. Cheong, Y. H., Kim1, C. Y., Chun, H. J., Moon, B. C., Park, H. C., Kim, J. K., Lee, S., Han, C., Lee, S. Y., and Cho, M. J. 2000. Molecular cloning of a soybean class III beta-1,3-glucanase gene that is regulated both developmentally and in response to pathogen infection. Plant Sci. 154:7181.

7. Collinge, D. B., Kragh, K. M., Mikkelsen, J. D., Nielsen, K. K., Rasmussen, U., and Vad, K. 1993. Plant chitinases. Plant J. 3:31-40.

8. Cook, D. W. M. 2002. A laboratory simulation for vectoring of Trichosporon pullulans by conidia of Botrytis cinerea. Phytopathology 92:12931299.

9. Domingo, C., Cnejere, V., and Vera, P. 1994. Genes encoding acidic and basic class III $\beta$-1,3-glucanase are expressed in tomato plants upon viroid infection. Plant Mol. Biol. 24:725-732.

10. Droby, S., Vinokur, V., Weiss, B., Cohen, L., Daus, A., Goldschmidt, E. E., and Porat, R. 2002. Induction of resistance to Penicillium digitatum in grapefruit by the yeast biocontrol agent Candida oleophila. Phytopathology 92:393-399.

11. Egea, C., Dickinson, M. J., Candela, M., and Candela, M. E. 1999. ß-1,3Glucanase isoenzymes and genes in resistant and susceptible pepper (Capsicum annuиm) cultivars infected with Phytophthora capsici. Physiol. Plant. 107:312-318.

12. El Ghaouth, A., Wilson, C. L., and Wisniewski, M. 2003. Control of postharvest decay of apple fruit with Candida saitoana and induction of defense responses. Phytopathology 93:344-348.

13. Fan, Q., and Tian, S. P. 2001. Postharvest biological control of grey mold and blue mold on apple by Cryptococcus albidus (Saito) Skinner. Postharvest Biol. Technol. 21:341-353.

14. Fan, Q., Tian, S. P., Liu, H. B., and Xu, Y. 2002. Production of $\beta-1,3-$ glucanase and chitinase of two biocontrol agents and their possible modes of action. Chin. Sci. Bull. 47:292-296.

15. Friendrich, L., Lawton, K., Ruess, W., Masner, P., Specker, N., Gut Rella, M., Meier, B., Dincher, S., Staub, S., and Uknes, S. 1996. A benzothiadiazole derivative induces systemic acquired resistance in tobacco. Plant J. 10:61-70.

16. Gonzalez-Bosch, C., Brummell, D. A., and Bennett, A. B. 1996. Differential expression of two endo-1,3- $\beta$-glucanase genes in pericarp and locules of wide-type and mutant tomato fruit. Plant Physiol. 111:13131319.

17. Guetsky, R., Shtienberg, D., Elad, Y., Fischer, E., and Dinoor, A. 2002. Improving biological control by combining biocontrol agents each with several mechanisms of disease suppression., Phytopathology 92:976-985.

18. Henrissat, B. 1991. A classification of glycosyl hydrolases based on amino acid sequence similarities. Biochem. J. 280:309-316.

19. Hoj, P. B., Rodriguez, E. B., Stick, R. V., and Stone, B. A. 1989. Differences in active site structure in a family of beta-glucan endohydrolases deduced from the kinetics of inactivation by epoxyalkyl beta-oligoglucosides. J. Biol. Chem. 264:4939-4947.

20. Ippolito, A., El-Ghaouth, A., Wilson, C. L., and Wisniewski, M. 2000. Control of postharvest decay of apple fruit by Aureobasidium pullulans and induction of defense responses. Postharvest Biol. Technol. 19:265272.

21. Jach, G., Gornhardt, B., Mundy, J., Logemann, J., Pinsdorf, E., Leah, R., Schell, J., and Mass, C. 1996. Enhanced quantitative resistance against fungal disease by combinational expression of different barley antifungal proteins in transgenic tobacco. Plant J. 8:97-109.

22. Jijakli, M. H., and Lepoivre, P. 1998. Characterization of an exo- $\beta-1,3-$ glucanase produced by Pichia anomala strain K, antagonist of Botrytis cinerea on apples. Phytopathology 88:335-343.

23. Kay, R., Chan, A., Daly, M., and McPherson, J. 1987. Duplication of CaMV 35S promoter sequences creates a strong enhancer for plant genes. Science 236:1299-1302.

24. Kessmann, H., Staub T., Hofmann, C., Maetzke, T., Herzog, J., Ward, E., Uknes, S., and Ryals, J. 1994. Induction of systemic acquired resistance in plants by chemicals. Annu. Rev. Phytopathol. 32:439-459.

25. Ko, T. S., Lee, S., Schaefer, S. C., and Korban, S. S. 2003. Characterization of a tissue-specific and developmentally regulated $\beta-1,3$-glucanase gene family in Prunus persica. Plant Physiol. Biochem. 41:955-963.

26. Lamb, C., and Dixon, R. A. 1997. The oxidative burst in plant disease resistance. Annu. Rev. Plant Physiol. Plant Mol. Biol. 48:251-275.

27. Lawrence, C. B., Joosten, M. H. A. J., and Tuzun, S. 1996. Differential induction of pathogenesis-related proteins in tomato by Alternaria solani and the association of a basic chitinase isozyme with resistance. Physiol. Mol. Plant Pathol. 48:361-377.

28. Lawton, K., Friedrich, L., Hunt, M., Weymann, K., Kessmann, H., Staub, T., and Ryals, J. 1996. Benzothiadiazole induces disease resistance in Arabidopsis by activation of the systemic acquired resistance signal 
transduction pathway. Plant J. 10:71-82

29. Leubner-Metzger, G., and Meins, F., Jr. 1999. Functions and regulation of plant $\beta$-1,3-glucanases (PR-2). Pages 49-76 in: Pathogenesis-Related Proteins in Plants. S. K. Datta and S. Muthukrishnan, eds. CRC Press, Boca Raton, FL.

30. Linthorst, H. J. M., Melchers, L. S., Mayers, A., van Roekel, J. S. C., Cornelissen, B. J. C., and Bol, J. F. 1990. Analysis of gene families encoding acidic and basic beta-1,3-glucanases of tobacco. Proc. Natl. Acad. Sci. USA 87:8756-8760.

31. Llop-Tous, I., Dominguez-Puigjaner, E., Palomer, X., and Vendrell, M. 1999. Characterization of two divergent endo 1,4- $\beta$-glucanase clones high expressed in the nonclimacteric strawberry fruit. Plant Physiol. 119:4151422.

32. Masih, E. I., and Paul, B. 2002. Secretion of beta-1,3-glucanases by the yeast Pichia membranifaciens and its possible role in the biocontrol of Botrytis cinerea causing grey mold disease of the grapevine. Curr. Microbiol. 44:391-395.

33. Meadus, W. J. 2003. A semi-quantitative RT-PCR method to measure the in vivo effect of dietary conjugated linoleic acid on porcine muscle PPAR gene expression. Biol. Procedures Online 5:20-28.

34. Meins, F., Jr., Neuhaus, J. M., Sperisen, C., and Ryfal, J. 1992. The primary structure of plant pathogenesis-related glucanohydrolases and their genes. Pages 245-282 in: Genes Involved in Plant Defense. T. Boller and F. Meins, Jr., eds. Springer Verlag, Vienna.

35. Morohashi, Y., and Matsushima, H. 2000. Development of $\beta-1,3-$ glucanase activity in germinated tomato seeds. J. Exp. Bot. 51:1381-1387.

36. Nakai, K., and Kanehisa, M. 1991. Expert system for predicting protein localization sites in gram-negative bacteria. Proteins 11:95-110.

37. Payne, G., Ward, E., Gaffney, T., Ahl-Goy, P., Moyer, M., Harper, A., Meins, F., Jr., and Ryals, J. 1990. Evidence for a third structural class of beta-1,3-glucanase in tobacco. Plant Mol. Biol. 15:797-808.

38. Peumans, W. J., Barre, A., Derycke, V., Rouge, P., Zhang, W., May, G. D., Delcour, J. A., van Leuven, F., and van Damme, E. J. 2000. Purification, characterization and structural analysis of an abundant beta-1,3-glucanase from banana fruit. Eur. J. Biochem. 267:1188-1195.

39. Qin, Q. Z., and Tian, S. P. 2004. Biocontrol of postharvest diseases of jujube fruits by Cryptococcus laurentii combined with a low dosage of fungicides under different storage conditions. Plant Dis. 88:497-501.

40. Ryals, J. A., Neuenschwander, U. H., Willits, M. G., Molina, A., Steiner, H., and Hunt, M. D. 1996. Systemic acquired resistance. Plant Cell 8:1809-1819.

41. Schroder, M., Hahlbrock, K., and Kombrink, E. 1992. Temporal and spatial patterns of $\beta$-1,3-glucanase and chitinase induction in potato leaves infected by Phytophthora infestans. Plant J. 2:161-172.
42. Simmons, C. R. 1994. The physiology and molecular biology of plant 1,3- $\beta$-D-glucanases and 1,3;1,4- $\beta$-D-glucanases. Crit. Rev. Plant Sci. 13:325-387.

43. Sticher, L., Mauch-Mani, B., and Metraux, J. P. 1997. Systemic acquired resistance. Annu. Rev. Phytopathol. 35:235-270.

44. Thimmapuram, J., Ko, T. S., and Korban, S. S. 2001. Characterization and expression of $\beta$-1,3-glucanase genes in peach. Mol. Genet. Genomics 265:469-479.

45. Tian, S. P., Qin, G. Z., and Xu, Y. 2005. Synergistic effects of combining biocontrol agents with silicon against postharvest diseases of jujube fruit. J. Food Prot. 68:544-550.

46. Trainotti, L., Spolaore, S., Ferrarese, L., and Csadoro, G. 1997. Characterization of ppEG1, a member of a multigene family which encodes endo 1,4- $\beta$-glucanases in peach. Plant Mol. Biol. 34:791-802

47. Usall, J., Teixidó, N., Fons, E., and Viñas, I. 2000. Biological control of blue mould on apple by a strain of Candida sake under several controlled atmosphere conditions. Int. J. Food Microbiol. 58:83-92.

48. van Loon, L. C. 1997. Induced resistance in plants and the role of pathogenesis-related proteins. Eur. J. Plant Pathol. 103:753-765.

49. van Loon, L. C., Bakker, P. A., and Pieterse, C. M. 1998. Systemic resistance induced by rhizosphere bacteria. Annu. Rev. Phytopathol. 36:453-483.

50. Von Heijne, G. 1986. A method for predicting signal sequence cleavage sites. Nucleic Acids Res. 11:4683-4690.

51. Wilson, C. L., and Chalutz, E. 1989. Postharvest biological control of Penicillium rots of citrus with antagonistic yeasts and bacteria. Sci. Hortic. 40:105-112.

52. Wisniewski, M., Biles, C., Droby, S., McLaughlin, R., Wilson, C., and Chalutz, E. 1991. Mode of action of the postharvest biocontrol yeast, Pichia guilliermondii: I. characterization of attachment to Botrytis cinerea. Physiol. Mol. Plant Pathol. 39:245-258.

53. Wu, C. T., and Bradford, K. J. 2003. Class I chitinase and $\beta$-1,3-glucanase are differentially regulated by wounding, methyl jasmonate, ethylene, and gibberellin in tomato seeds and leaves. Plant Physiol. 133:263-273.

54. Wu, C. T., Leubner-Metzger, G., Meins, F., Jr., and Bradford, K. J. 2001. Class I $\beta$-1,3-glucanase and chitinase are expressed in the micropylar endosperm of tomato seeds prior to radicle emergence. Plant Physiol. 126:1299-1313.

55. Yao, H. J., and Tian, S. P. 2005. Effects of a biocontrol agent and methyl jasmonate on postharvest diseases of peach fruit and the possible mechanisms involved. J. Appl. Microbiol. 98:941-950.

56. Zhou, J. M. 1999. Signal transduction and pathogen-induced PR gene expression. Pages 195-205 in: Pathogenesis-Related Proteins in Plants. S. K. Datta and S. Muthukrishnan, eds. CRC Press, Boca Raton, FL. 